\title{
ADMIRALTY: RIGHTS OF CONTRIBUTION AND EXONERATION ESTABLISHED BETWEEN COEXTENSIVE MAINTENANCE AND GURE OBLIGORS
}

\begin{abstract}
Emphasizing the extent of equity discretion available to admiralty courts, the Court of Appeals for the Third Circuit ruled that maintenance and cure expenses resulting from a seaman's "recurring" injury should be borne equally by the obligor liable for the original injury and the owner in whose employ the injury was heightened. However, where the injury has resulted from the violation of a duty owed the seaman by either obligor, the total liability is the responsibility of the offending party. Although determining the extent of contribution in an inequitable albeit facile manner, the decision bars arbitrary imposition of liability and significantly indicates judicial disfavor of the traditional impediments to loss distribution in maritime law.
\end{abstract}

\begin{abstract}
A Admiralty has long recognized the liability of a shipowner for medical and living expenses of a seaman who, without wilful misbehavior on his part, becomes ill or is in any way injured in the service of the ship. ${ }^{1}$ Since this liability for maintenance and cure does not automatically terminate when a seaman is employed by a second shipowner, ${ }^{2}$ the obligation may be simultaneously borne by both employers if the seaman's original injury recurs ${ }^{3}$ during the

1 The maintenance and cure right "stems from the ancient sea codes of the Middle Ages which have been aptly termed "the common law of the sea." 1 M. NorRIs, TrE LAw OF SEAMEN $\$ 538$ (2d ed. 1962) (author's footnote omitted) [hereinafter cited as Norris]. See, e.g., Laws OF OLERoN arts. VI-VII, 30 F. Cas. 1171, 1174-75; LAws of WISBUY arts. XVIII, XIX, \& XXXIII, 30 F. Cas. 1189, 1191-92. Recovery encompasses "wages to the end of the voyage and subsistence, lodging and care to the point where the maximum cure attainable has been reached." I NorRIs \$537. See generally Aguilar v. Standard Oil Co., 318 U.S. 724, 727-36 (1943); Bensing \& Friedman, The Law of Admiralty- $A$ Primer, 11 W. REs. L. Rev. 21, 43-46 (1959); Bradley, An Introduction to Admiralty and Maritime Law, 1959 U. IL.L. L.F. 81, 93-94; Levinson, Current Developments in the Field of Maintenance and Cure, 11 NACCA L.J. 140 (1953); Comment, Admiralty Right to Maintenance and Cure, 38 IL.. L. Rev. 193 (1943); Comment, Admiralty-Maintenance and Cure, 50 MIcH. L. REv. 435 (1952).

${ }^{2}$ E.g., Permanente S.S. Corp. v. Martinez, 369 F.2d 297, 299 (9th Cir. 1966). See notes 19-21 infra and accompanying text.

"Where an injury "recurs" it cannot be maintained that an actual "cure" had been effected subsequent to the initial injury. For the "recurrence" to create a coextensive maintenance and cure obligation, the original injury must be a substantial cause of the subsequent disability. See Gore v. Clearwater Shipping Corp., 378 F.2d 584 (3d Cir. 1967). Recovery for recurrence of an injury sustained in a prior employment is predicated upon the long-recognized principles that a shipowner is responsible for maintenance and cure to a seaman displaced in the vessel's service, Aguilar v. Standard
\end{abstract}


subsequent service. ${ }^{4}$ Recently, in Gooden v. Sinclair Refining Company, ${ }^{5}$ the Court of Appeals for the Third Circuit established rights of contribution and exoneration to determine ultimate liabilities between two shipowners having coextensive obligations. The decision, although generally precluding arbitrary imposition of the expense, fails to promulgate a scheme of apportionment consistent with the basic characteristics of the maintenance and cure obligation. Nevertheless, the rationale of the decision may adumbrate reconsideration of other rules governing joint liabilities in admiralty.

Seaman Gooden suffered a back injury while employed by Texaco. Deemed fit for duty by the Public Health Service after extensive medical treatment, Gooden subsequently was engaged as a seaman by Sinclair Refining Company. Because of a recurrence of the original injury, however, Gooden was shortly thereafter required to leave Sinclair's employ for further treatment. ${ }^{\circledR}$ Although separate libels for maintenance and cure against Texaco and Sinclair were initially instituted, the suits were consolidated for trial upon Sinclair's impleader of Texaco. ${ }^{7}$ The district court allowed judgment against only Sinclair for maintenance and cure expenses arising subsequent to Gooden's service with that employer, ${ }^{8}$ but further held Sinclair entitled to reimbursement by Texaco for the cost of the recovery. ${ }^{9}$ Reversing on appeal, the circuit court held that Sinclair had a right

Oil Co., 318 U.S. 724, 730-32 (1943), and that a maintenance and cure obligation does not depend upon any causal connection between the disability and the service, Farrell v. United States, 336 U.S. 511, 515-16 (1949); Diaz v. Gulf Oil Corp., 237 F. Supp. 261, 263 (S.D.N.Y. 1965).

- Compare Diaz v. Gulf Oil Corp., 237 F. Supp. 261, 266 (S.D.N.Y. 1965) (recovery from last vessel where recurring disease has become manifest), with Pyles v. Amcrican Trading and Prod. Corp., 244 F. Supp. 685, 687 (S.D. Tex. 1965), modified on other grounds, 372 F.2d 611 (5th Cir. 1967) (recovery from vessel where disability originatcd despite subsequent employment as seaman).

5 378 F.2d 576 (3d Cir. 1967), noted in 13 VILL. L. REv. 187 (1967).

${ }^{\circ} 378 \mathrm{~F} .2 \mathrm{~d}$ at 578 .

IId.

${ }^{8}$ Gooden v. Texaco, Inc., 255 F. Supp. 343, 347-48 (E.D. Pa. 1966). Since a co. extensive obligation existed only as to the expenses incurred after Gooden's cmployment with Sinclair, those expenses produced the principal dispute in the case. See 378 F.2d at 580 n.4. The district court rendered judgment against Sinclair, reasoning that as a matter of convenience Gooden should be allowed to secure total recovery from the last vessel on which he served. To avoid duplicity of recovery, however, judgment was not allowed against Texaco for that period. 255 F. Supp. at 348. The circuit court, on the other hand, concluded that the seaman should have been awarded judgment in full against both Sinclair and Texaco in order to protect his right to collect from either owner. 378 F.2d at 579 n.3.

${ }^{\circ} 255$ F. Supp. at 348. 
to complete exoneration only if Texaco's negligence ${ }^{10}$ or a breach of its absolute duty to provide a seaworthy ship ${ }^{11}$ had led to Gooden's injury. ${ }^{12}$ If neither shipowner had breached a duty, ultimate maintenance and cure liability was to be distributed equally by means of contribution. ${ }^{13}$

The shipowner's duty to provide maintenance and cure is not dependent upon his culpability, ${ }^{14}$ but arises merely from the fact of employment.15 The duty is deemed so important to the shipownerseaman relationship that it survives any attempted contractual negation. ${ }^{16}$ Since prompt restoration to service of disabled seamen is in

${ }^{10}$ Section 33 of the Jones Act provides that "any seaman who shall suffer personal injury in the course of his employment may, at his election, maintain an action for damages at law ...." 46 U.S.C. $\$ 688$ (1964). Thus, if Texaco's negligence were the cause of Gooden's original injury, the seaman would have an action for compensatory damages against the company. See generally Bensing \& Friedman, supra note 1, at 48-51; Comment, Seamen's Injuries: The Jones Act, Unseaworthiness, and Maintenance and Cure-The Siamese Triplets, 51 GALIF. L. REv. 412 (1963). The court in Gooden reasoned that since primary liability rests on the party liable in compensatory damages, the party merely secondarily liable should be granted exoneration. See notes 82-84 infra and accompanying text.

11 A shipowner is liable in compensatory damages "for injuries received by seamen in consequence of the unseaworthiness of the ship, or a failure to supply and keep in order the proper appliances appurtenant to the ship." The Osceola, 189 U.S. 158, 175 (1903). See generally Bensing \& Friedman, supra note I, at 46-48; Foley, A Survey of the Maritime Doctrine of Seaworthiness, 46 ORE. L. REV. 369 (1967); Comment, The Doctrine of Unseaworthiness in the Law of Maritime Personal Injuries, 21 LA. L. REv. 755 (1961); Note, The Doctrine of Unseaworthiness: Developing Restriction of the Act-Condition Dichotomy, 21 RuTGers L. Rev. 322 (1967); Comment, Expanding the Warranty of Seaworthiness: Social Welfare or Maritime Disaster, 9 VILI. L. REv. 422 (1964); Comment, Risk Distribution and Seaworthiness, 75 YALE L.J. 1174 (1966).

$12378 \mathrm{~F} .2 \mathrm{~d}$ at 581 .

${ }^{13} \mathrm{Id}$. See notes $54-59$ infra and accompanying text.

14 See, e.g., The Osceola, 189 U.S. 158, 175 (1903); 1 NorRIs \$537; Bradley, supra note 1, at 93; Morrison, Maintenance and Cure and Farrell v. United States, 6 MuAm L.Q. 168, 172-73 (1952); Slaughter, Basic Principles of the Law of Admiralty, 19 ARK. L. Rev. 93, 105 (1965); Stern, Duration of Seamen's Maintenance and Cure Rights, 8 Clev.-Mar. L. REV. 275, 278 (1959).

${ }^{16}$ E.g., Vaughan v. Atkinson, 369 U.S. 527, 532-33 (1962), quoting Cortes v. Baltimore Insular Line, Inc., 287 U.S. 367, 371 (1932); see I NorRis \$ 545.

20 Vaughan v. Atkinson, 369 U.S. 527, 532-33 (1962), quoting Cortes v. Baltimore Insular Line, Inc., 287 U.S. 367, 371 (1932). The following observation has been made concerning the policy underlying imposition of the maintenance and cure obligation: "It encourages seamen to engage in perilous voyages with more promptitude, and at lower wages. It diminishes the temptation to plunderage upon the approach of sickness; and urges the seaman to encounter hazards in the ship's service, from which they might otherwise be disposed to withdraw." Harden v. Gordon, 11 F. Cas. 480, 483 (No. 6047) (C.C.D. Me. 1823) (Story, J.). The Supreme Court has recently related this policy to contemporary commercial practice. Vaughan v. Atkinson, supra at 531-33. See also G. GLlmoRe \& C. BLACK, ThIE LAw OF Admiralty \$6-6 (1957) [hereinafter cited as GILMORE \& BLACK]; Bradley, supra note 1, at 93-94. 
both the national interest and that of individual shipowners, ${ }^{17}$ the seaman's right to recovery continues until no further improvement in the seaman's condition may be reasonably expected from medical care..$^{18}$ Generally, re-employment on another vessel ${ }^{10}$ or issuance of a fit-for-duty slip by the Public Health Service ${ }^{20}$ evidences, but does not conclusively demonstrate, the fact of maximum medical recovery. ${ }^{21}$

Maintenance and cure is a right only to the necessary living and care expenses engendered by the disability ${ }^{22}$ and does not constitute an award of compensation for damages suffered. ${ }^{23}$ Recovery in an action for compensatory damages does not, therefore, prohibit a separate suit based upon the shipowner's non-tort obligation. ${ }^{24}$ A seaman is, however, entitled to only one recovery of his medical and subsistence expenses. ${ }^{25}$ Since a judgment for compensatory damages will very probably encompass losses equally recoverable under maintenance and cure, ${ }^{26}$ admiralty has consistently provided that an in-

\footnotetext{
${ }^{17}$ See Calmar S.S. Corp. v. Taylor, 303 U.S. 525, 528-29 (1938); Harden v. Gordon, 11 F. Cas. 480, 483 (No. 6047) (C.C.D. Me. 1823); Gilmore \& BLACK § 6-6.

${ }^{18}$ See, e.g., Calmar S.S. Corp. v. Taylor, 303 U.S. 525, 529-32 (1938). The period of time for maximum medical recovery is generally construed liberally in the seaman's favor. See Vaughan v. Atkinson, 369 U.S. 527, $531-33$ (1962); Stern, supra note 14.

${ }^{10} 1$ NorRis $\$ 561$; see, e.g., Hanson v. Rciss S.S. Co., 184 F. Supp. 545, 550 (D. Del. 1960); cf. Campbell v. Tidewater Associated Oil Co., 141 F. Supp. 431, 435 (S.D.N.Y. 1956).

${ }^{20}$ I NorRIs $\$ 561$; see, e.g., Dobbs v. Lykes Bros. S.S. Co., 243 F.2d 55 (5th Cir.), cert. denied, 355 U.S. 835 (1957); Koleris v. S.S. Good Hopc, 241 F. Supp. 967, 970 (E.D. Va. 1965).

${ }^{21}$ E.g., Permanente S.S. Corp. v. Martinez, 369 F.2d 297, 299 (9th Cir. 1966); Dinicro v. United States Lines Co., 185 F. Supp. 818, 820 (S.D.N.Y. 1960), aff'd, 288 F.2d 595 (2d Cir.), cert. denied, 368 U.S. 831 (1961).

${ }^{22}$ See McCarthy v. American E. Corp., 175 F.2d 727, 729 (3d Gir. 1949), cert. denied, 338 U.S. 911 (1950).

${ }^{28}$ See, e.g., Calmar S.S. Corp. v. Taylor, 303 U.S. 525, 528 (1938). The seaman may also maintain at his election an action to recover compensatory damages for his employer's negligence under $\$ 33$ of the Jones Act, 46 U.S.C. $\$ 688$ (1964), or on a theory of unseaworthiness, see notes 10-11 supra. See generally Comment, Seamen's Injuries: The Jones Act, Unseaworthiness, and Maintenance and Cure-The Siamese Triplets, 51 CALIF. L. REv. 412 (1963).

2s See, e.g., Permanente S.S. Corp. v. Martinez, 369 F.2d 297, 300 (9th Cir. 1966); Bartholomew v. Universe Tankships, Inc., 279 F.2d 911, 915-16 (2d Cir. 1960). See generally Comment, Seamen's Injuries: The Jones Act, Unseaworthiness, and Maintenance and Cure-The Siamese Triplets, 51 CALIF. L. REv. 412 (1963).

${ }^{25}$ E.g., Bartholomew v. Universe Tankships, Inc., 279 F.2d 911, 913 (2d Cir. 1960); McCarthy v. American E. Corp., 175 F.2d 727, 729 (3d Cir. 1949), cert. denicd, 338 U.S. 911 (1950). Since maintenance and cure is intended only to provide what the seaman would receive aboard ship, a seaman is not entitled to "six meals a day." McCarthy v. American E. Corp., supra.

${ }^{20}$ In actions based upon allegations of unseaworthiness or negligencc, the clements
} 
jured seaman may not recover from his employer those elements of maintenance and cure which have been previously recovered from him or from a third-party tortfeasor in the form of compensatory damages. $^{27}$ It has not been judicially determined, however, whether a shipowner may obtain relief from some part of his obligation by virtue of compensatory damages paid the seaman during a prior employ.

Although the liability of a maintenance and cure obligor may be mitigated by the rule against double recovery when the seaman first recovers from a third-party tortfeasor, ${ }^{28}$ this limitation may not obtain where the seaman chooses initially to exercise his non-tort right. Consequently, a divergence of opinion has arisen with regard to the right of the maintenance and cure payor to indemnity from the tortfeasor whose negligence has resulted in injury to a seaman in the payor's employ. ${ }^{20}$ In The Federal No. 2,30 a right to indemnity was refused on the ground that the maintenance and cure obligation is contractual in nature and therefore the proximate cause of the shipowner's damage was the employment relationship, not the tortious act. ${ }^{31}$

of damage recoverable are past and prospective medical expenses, past and prospective loss of earnings, and an additional sum to compensate for physical injuries and pain and suffering. Bartholomew v. Universe Tankships, Inc., 279 F.2d 911, 916 (2d Cir. 1960); 1 NoRris $\$ 608$. Subsistence, lodging, and necessary care and medical expenses which comprise maintenance and cure are thus likely to be included in the foregoing elements of compensatory damages. See McCarthy v. American E. Corp., 175 F.2d 727, 729 (3d Cir. 1949), cert. denied, 338 U.S. 911 (1950).

${ }^{27}$ See McCarthy v. American E. Corp., 175 F.2d 727 (3d Cir. 1949), cert. denied, 338 U.S. 911 (1950); The Jefferson Myers, 45 F.2d 162 (2d Cir. 1930); Seely v. New York, 24 F.2d 412 (2d Cir. 1928); Thibeault v. Boston Towboat Co., 28 F. Supp. 152, 158 (D. Mass. 1939), aff'd sub nom. Mystic Terminal Co. v. Thibeault, 108 F.2d 813 (1st Cir. 1940).

${ }^{28}$ See cases cited note 27 supra.

${ }^{20}$ See generally GILMORE \& BLACK $\$ \$ 6-14$ to -18 ; Note, Shipowner's Indemnity: Non-Contractual Recovery of Maintenance and Cure Expenses from Third Party TortFeasor, 18 HASTings L.J. 1008 (1967).

${ }^{30} 21 \mathrm{~F} .2 \mathrm{~d} 313$ (2d Cir. 1927). In this case, a seaman employed on a barge was injured by a tug's towing hawser which swept across the deck of the barge. The barge owner, upon paying the seaman's expenses, libeled the tug in rem for reimbursement of the expenses.

31 Id. at 313-14. The court's rationale and consequent denial of indemnity received much contemporary criticism. See Note, 12 CoRNeld L.Q. 235 (1927); 27 Colum. L. Rev. 212 (1927); 76 U. PA. L. REv. 326 (1928); 37 YALE L.J. 533 (1928). The validity of the result has also been questioned in light of subsequent decisions by the Second Circuit, e.g., The Jefferson Myers, 45 F.2d 162 (2d Cir. 1930), and Seely v. New York, 24 F.2d 412 (2d Cir. 1928), which held that the liability of the seaman's employer for maintenance and cure is secondary to that of one who has neligently injured the seaman. See Sillanpa v. Cornell Steamboat Co., 1954 A.M.C. 1189 (N.Y. Sup. C.). A recent commentator has argued that The Federal No. 2 would be decided differently today in hight of Ryan Stevedoring Co. v. Pan-Atlantic S.S. Corp., 350 U.S. 124 (1956), wherein the Supreme Court granted indemnity to a shipowner for losses occasioned by 
Those cases allowing a parent to recover from a third-party tortfeasor for loss of a child's services were distinguished by characterization of the parental obligation as of a higher moral and social order than the employer-employee contractual relation..$^{32}$ Conversely, in Jones v. Waterman Steamship Corporation ${ }^{33}$ indemnity was granted to the maintenance and cure payor on the basis that an employer's right to recover for loss resulting from negligent disablement of his employees by a third party was "settled" law in the United States. $^{34}$ Moreover, the court adopted the analogy of the shipowner-seaman relationship to that of parent and child since seamen, traditionally "wards" of the admiralty, are viewed as "children" by maritime law. ${ }^{35}$ Although the continuing validity of the

third parties performing services for the owner. See Note, Shipowner's Indemnity: Non-Gontractual Recovery of Maintenance and Cure Expenses from Third Party TortFeasor, 18 Hastings L.J. 1008 (1967). Nevertheless, several courts have followed The Federal No. 2. See H-10 Water Taxi Co. v. United States, 252 F. Supp. 592 (S.D. Cal. 1966), affd, 379 F.2d 963 (9th Cir. 1967); Gomes v. Eastern Gas \& Fuel Associates, 127 F. Supp. 435, 437-38 (D. Mass. 1954); Irwin v. United States, 111 F. Supp. 912 (E.D.N.Y. 1953), affd, 236 F.2d 774 (2d Cir. 1956); Houston Belt \& Terminal Ry. v. Burmester, 309 S.W.2d 271, 277-79 (Tex. Civ. App. 1957).

32 21 F.2d at 314. The court observed that a father's recovery for injury of his child is based upon the natural parental obligation, the implications of which the tortfeasor is expected to comprehend. However, since the shipowner-seaman obligation is contractual rather than social, the tortfeasor is not presumed to be aware of the consequences of that relationship. Thus, the analogy fails. Id. But see Jones v. Waterman S.S. Corp., 155 F.2d 992, 1000-01 (3d Cir. 1946). See also notes 34.35 infra and accompanying text.

${ }^{38} 155$ F.2d 992 (3d Cir. 1946). In Jones a seaman left his ship at night and fell into an open ditch beside a railroad track. The seaman settled his claim against Reading for $\$ 750$ and executed a general release. He also brought a civil action against his employer for maintenance and cure. The employer impleaded Reading as $a$ third-party defendant. The release was held not to bar either the seaman's action against his employer or the employer's claim against Reading. Id. at 996. Several other courts have indicated subsequently that indemnity is available to a maintenance and cure obhgor. See Myles v. Quinn Menhaden Fisheries, Inc., 302 F.2d 146, 151 (5th Cir. 1962); Valentine v. Wiggins, 242 F. Supp. 870, 872 (E.D.N.C. 1965); Pure Oil Co. v. Geotechnical Corp., 129 F. Supp. 194, $197-98$ (E.D. La. 1955); Pabellon v. Grace Line, Inc., 12 F.R.D. 123 (S.D.N.Y. 1951); Sillanapa v. Cornell Steamboat Co., 1954 A.M.C. 1189 (N.Y. Sup. Ct.).

36 155 F.2d at 998 \& n.6. The court of appeals observed that an employer's right at common law to compensatory damages for injury of his servant by the tortious act of another extended only to compensation for loss of service, but reasoned that since the shipowner cannot escape the duty to provide the seaman's maintenance and cure any more than it could escape the loss of services, recovery for the maintenance and cure expense should also be allowed. Id. at 1000.

${ }^{35} I d$. at $1000-01$. The court reached an opposite conclusion to that of the second circuit in The Federal No. 2 concerning the analogy of the shipowner and seaman to the parent and child. See note 32 supra and accompanying text. Observing that the obligations of the ship to its seamen do not rest solely in contract but are imposed by the courts as a matter of public policy, id. at 1000; see Norris, The Seaman As 
Jones rationale is uncertain, ${ }^{36}$ commentators have generally favored its result ${ }^{37}$ since indemnification of the shipowner does not increase the tortfeasor's original liability ${ }^{38}$ and eviscerates the power of the seaman to arbitrarily determine ultimate liabilities. ${ }^{39}$

Unlike indemnity, which leads to complete remuneration, contribution is a right to reimbursement of only a ratable proportion of the seaman's total recovery. ${ }^{40}$ Although not previously utilized to distribute maintenance and cure obligations, contribution has been consistently granted in admiralty to apportion certain losses arising from causes other than fault by means of the "general average." 41 If a voluntary jettison of a part of the vessel or of its cargo promotes the safety of either in the face of an imminent peril, the owners of both the cargo and the vessel must contribute in proportion to the value of their participating interests. ${ }^{42}$ Decrees for this contribution in general average rest exclusively on the "equitable" principle that those confronted with a common risk should bear the costs of that risk in some manner reasonably related to the benefits each will derive from the commercial venture.43

Contribution has also been traditionally recognized as a means

Ward of the Admiralty, 52 MICH. L. REV. 479 (1954), the court preferred "to impose a higher degree of dignity upon the ship-seaman relationship, awarding to it a status or a 'social condition' in excess of that given under the ruling in The Federal No. 2." $155 \mathrm{~F} .2 \mathrm{~d}$ at 1001 .

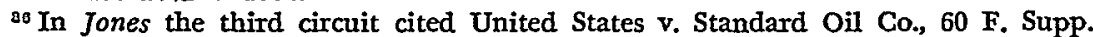
807 (S.D. Cal. 1945), which held that the United States was entitled to indemnity from a third-party tortfeasor for hospital expenses paid as a result of the injury of a soldier. Subsequent to the Jones decision, however, the Supreme Court affirmed a circuit court reversal of Standard Oil. United States v. Standard Oil Co., 332 U.S. 301 (1947), affg 153 F.2d 958 (9th Cir. 1946), rev'g 60 F. Supp. 807 (S.D. Cal. 1945). Whether this actually debilitated the result in Jones is disputed. Compare Gomes v. Eastern Gas \& Fuel Associates, 127 F. Supp. 435, 437-38 (D. Mass. 1954) (following the Supreme Court in United States v. Standard Oil Co., supra), with Pure Oil Co. v. Geotechnical Corp., 129 F. Supp. 194, 198 (E.D. La. 1955) (following Jones).

at See 1 P. Edelman, MartTime Injury and Death 56-58 (1960); Gilmore \& Black $\$ 6 \cdot 18$.

88 GuMORE \& BLACK \$ 6-18.

so See note 65 infra and accompanying text.

${ }^{10}$ E.g., Herrero v. Atkinson, 227 Cal. App. 2d 69, 38 Cal. Rptr. 490 (1964); Putvin v. Buffalo Elec. Co., 5 N.Y.2d 447, 158 N.E.2d 691, 186 N.Y.S.2d 15 (1959).

¿1 See, e.g., Archawski v. Hanioti, 350 U.S. 532, 535 (1956); Barnard v. Adams, 51 U.S. (10 How.) 270, 303 (1850). See generally GLMare \& BLACK \$\$5-1 to -15; R. Lowndes \& G. Rudolf, Law of General Average aNd the York-ANTwerp Rules (8th ed. 1955); Bensing \& Friedman, supra note I, at 38-41; Felde, General Average and the York-Antwerp Rules, 27 TuL. L. REv. 406 (1953).

SSe GILMORE \& BLACK \$5-1, at 222; Bensing \& Friedman, supra note 1, at 39; Felde, supra note 41 , at 407 .

43 See Ray, Uniformity As a Common Goal, 10 J. Puв. L. 276, 279 (1961). 
of apportioning damages among joint tortfeasors in admiralty.4 Rather than merely an equitable adjustment, however, such apportionment is a substantive right arising directly from the tort.45 Originally propounded to assure equal distribution of loss when two vessels were at fault in a collision, ${ }^{46}$ this form of contribution was gradually extended to non-collision situations involving joint tortfeasors. ${ }^{47}$ This expanded utilization was terminated, however, by Halcyon Lines v. Haenn Ship Ceiling \& Refitting Corporation ${ }^{48}$ in which the Supreme Court declared that contribution among joint tortfeasors could be invoked only to distribute collision losses. ${ }^{40}$ Spe-

\footnotetext{
"See generally Staring, Contribution and Division of Damages in Admirally and Maritime Cases, 45 Gar.IF. L. REv. 304 (1957).

is See, e.g., Erie R.R. v. Eric \& W. Transp. Co., 204 U.S. 220, 225-26 (1907); Stradley v. Capital Transit Co., 87 F. Supp. 94 (D.D.C. 1949), aff'd, 183 F.2d 825 (D.C. Cir. 1950), rev'd on other grounds, 340 U.S. 543 (1951), quoting Drummond v. United States, 78 F. Supp. 730, 731 (E.D. Va. 1948) (dictum). Thus, the party sued for contribution in admiralty may not rely on personal defenses available against the injured party. See, e.g., The Tampico, 45 F. Supp. 174 (W.D.N.Y. 1942). But see United States v. Weyerhaeuser S.S. Co., 294 F.2d 179 (9th Cir. 1961), rev'd on other grounds, 372 U.S. 597 (1963). Neither may he rely upon a statute of limitations which would have barred the original libel. See, e.g., The Conemaugh, 135 F. 240 (N.D. Il. 1904).

${ }^{10}$ See Halcyon Lines v. Haenn Sbip Geiling \& Refitting Corp., 342 U.S. 282, 284 (1952); Ray, supra note 43, at 285. In adopting the moicty rule for collision cases in the United States, the Supreme Court observed that "[u]nder the cireumstances usually attending these disasters, we think the rule dividing the loss the most just and equitable, and as best tending to induce care and vigilance on both sides, in the navigation." The Schooner Catharine v. Dickinson, 58 U.S. (17 How.) 170, 177-78 (1854). There has been considerable pressure recently for the apportionment of damages in collision cases on the basis of degree of fault, see McKeel v. Schroeder, 215 F. Supp. 756, 759.60 (N.D. Cal. 1963); N.M. Paterson \& Sons v. Chicago, 209 F. Supp. 576 (N.D. Ill. 1962), rev'd, 324 F.2d 254 (7th Cir. 1963); GILMORE \& BLACK \$7-20; Ray, supra note 43, at $286-88$, since it is the prevailing rule in other nations, see Staring, stipra note 44 , at 338-44.

${ }^{77}$ In The Ira M. Hedges, 218 U.S. 264 (1910), the Supreme Court indicated that contribution was an integral part of admiralty and drew no distinction between different types of torts. Id. at 270. Subsequently, many lower court decisions specifically recognized the right in non-collision cases. See, e.g., Barbarino v. Stanhope S.S. Co., 151 F.2d 553, 555 (2d Gir. 1945); Barber S.S. Lines, Inc. v. Quinn Bros., 94 F. Supp. 212, 213 (D. Mass. 1950); Coal Operators Cas. Co. v. United States, 76 F. Supp. 681 (E.D. Pa. 1947); The S.S. Samovar, 72 F. Supp. 574, 588.89 (N.D. Cal. 1947). Bul see notes $48-49$ infra and accompanying text.

4842 U.S. 282 (1952). In this case a shipowner hired a land-based contractor to make repairs on the vessel. An employee of the contraetor was injured aboard slip and brought suit against the owner alleging negligence and unseaworthiness of the vessel. The owner brought in the contractor as a third-party defendant and the jury returned a special verdict finding the contractor $75 \%$ and the owner $25 \%$ responsible. Id. at 283.

${ }^{10}$ Id. at 284-85. The Court recognized the ancient origin of the collision moiety rule but observed that "this Court has never expressly applied it to non-collision cases." Id. at 284. Admitting the controversial nature of the rule, the Court nevertheless concluded that "it would be unwise to attempt to fashion new judicial rules
} 
cifically finding that a shipowner was not entitled to contribution from a non-shipowner employer of the injured party, the Court concluded that since Congress had enacted pervasive legislation governing maritime personal injury ${ }^{50}$ without granting such recovery, imposition of contribution in non-collision cases should await legislative approval.51 Though Halcyon may be distinguishable from previous decisions permitting apportionment since the non-contributing employer was not a tortfeasor under the applicable statute, ${ }^{52}$ the broad proscription of the decree has received general judicial acceptance. ${ }^{53}$

of contribution and that the solution of this problem should await congressional action." Id. at 285.

${ }^{50}$ At the time of the Halcyon decision, Congress had enacted the Longshoremen's and Harbor Workers' Compensation Act, ch. 509, $\$$ 1-50, 44 Stat. 1424 (1927) (now 33 U.S.C. $\$ \$ 901-50$ (1964)); the Limited Liability Act of 1871, ch. 100, $\$ \S 1-59$, I6 Stat. 440; the Harter Act, ch. 105, $\$ 11-6,27$ Stat. 445 (1893) (now 46 U.S.C. $\$ \$ 190-96$ (1964)); the Jones Act, ch. 250, $\$ 33,41$ Stat. 1007 (1920) (now 46 U.S.C. $\$ 688$ (1964)); and the Public Vessels Act, ch. 428, $\$ \S 1-10,43$ Stat. 1112 (1925) (now 46 U.S.C. $\$ \S 781-90$ (1964)). See 342 U.S. at 285-86.

E1 342 U.S. at 285-87. In the opinion of the Court, Congress was best adapted to consider the varying interests of the shipowners, seamen, stevedores, longshoremen, and insurance companies iuvolved, $i d$. at 286 , and thus a resolution of these interests by judicial rule would be unwise. See note 49 supra.

52 See Staring, supra note 44 , at $305 \mathrm{n} .9,345$.

Es See, e.g., Crawford v. Pope \& Talbot, Inc., 206 F.2d 784, 791-93 (3d Cir. 1953); Horan v. Pope \& Talbot, Iuc., 115 F. Supp. 32, 33 (E.D. Pa. 1952). But see Russell, Poling \& Co. v. United States, 140 F. Supp. 890, 892-93 (S.D.N.Y. 1956) (affirming right of contribution in stranding cases).

Subsequent to Halcyon, the Supreme Court granted a shipowner the right to indemnity from a land-based contractor whose acts were the sole affirmative cause of the shipowner's liability to the contractor's employee. See Italia Societa per Azioni di Navagazione v. Oregon Stevedoring Co., 376 U.S. 315 (1964) (implied indemnity available where injury caused by stevedore's unseaworthy equipment); Waterman S.S. Corp. v. Dugan \& McNamara, Inc., 364 U.S. 421 (1960) (implied indemnity available where there is no actual contract); Crumady v. The Joachim Hendrik Fisser, 358 U.S. 423 (1959) (same); Weyerhaeuser S.S. Co. v. Nacierma Operating Co., 355 U.S. 563 (1958) (implied indemnity under the contract between stevedore and shipowner); Ryan Stevedoring Co. v. Pan-Atlantic S.S. Corp., 350 U.S. 124 (1956) (same). Thus, "in the framework of harbor-worker litigation, there are simply no cases left for the Halcyon rule to apply unless it be imagined that the harbor-worker's employer was a trespasser on the ship." Gilmore \& BLAcK $\$ 6-57$, at 371. Furthermore, the author of the Halcyon opinion, Mr. Justice Black, has noted that in Halcyon the Court "held that the system of compensation which Congress established in the Longshoremen's and Harbor Workers' Compensation Act $[33$ U.S.C. $\$ \$ 901-50$ (I964)] as the sole liability of a stevedoring company to its employees prevented a shipowner from shifting all or part of his liability to the injured longshoreman onto the stevedoring company, the longshoreman's employer." Italia Societa per Azioni di Navigazione v. Oregon Stevedoring Co., supra at 325 (dissenting opinion). Whether that was the primary basis of the Halcyon decision, however, was not specifically indicated by the majority opinion. See notes 50-52 supra and accompanying text. On the other hand, if Mr. Justice Black was correct, then implied indemnity has undermined that basis by depriving the employer of his protection of limited liability. 
In Gooden, the circuit court refused to find the Halcyon limitations applicable to contribution for maintenance and cure since the infringement of legislative policy and extension of shipowner's liability found debilitating to a contribution rule in the joint tortfeasor situation ${ }^{54}$ were not relevant in the maintenance and cure co-obligor context. ${ }^{55}$ Moreover, the court rejected the contention that ultimate liability should rest with the shipowner under whose employ the disability originated, reasoning that where neither employer has violated a legal duty neither should bear a greater part of the legal obligation..$^{56}$ Rather, emphasizing the power of admiralty courts to fashion rules for which there is no precise precedent, ${ }^{67}$ the court relied upon equitable principles ${ }^{58}$ to provide that ultimate lia-

is See Halcyon Lines v. Haenn Ship Ceiling \& Refitting Corp., 342 U.S. 282, 28586 (1952); note 55 infra. The court in Gooden assumed from Mr. Justice Black's dissenting opinions subsequent to Halcyon, see note 53 supra, that the Falcyon decision "was designed to preserve an employee's rights in full while at the same time limiting an employer's liability to that provided by Congress." $378 \mathrm{~F} .2 \mathrm{~d}$ at 583, citing Ryan Stevedoring Co. v. Pan-Atlantic S.S. Corp., 350 U.S. 124, 135 (1956) (Black, J., dissenting).

w The Gooden court concluded that the considerations militating against the adoption of a contribution rule in Halcyon, see notes 50-51 supra and accompanying text, were not controlling since reimbursement rights do not increase existing liahilitics of shipowners to seamen, restrict a seaman's ability to recover, or impinge upon other expressed legislative policies. $378 \mathrm{~F} .2 \mathrm{~d}$ at 583 .

${ }^{56} 378$ F.2d at 580: "If the accident occurred even though Texaco exercised duc care, maintained a seaworthy ship, and violated no other duty owed the scaman, its obligation toward the seaman during this period stands on precisely the same footing as Sinclair's: a disability arising while the seaman was in the service of the ship. Therefore, apart from a showing that Texaco violated a duty owed the seaman which caused lis disability, we conclude that Sinclair and Texaco should share equally their coextensive obligation to provide maintenance and cure."

${ }^{57}$ Id. at 583. The court justified the creation of reimbursement rights as a "performance of the Court's function in declaring the general maritime law, frec from inappropriate common-law concepts." Id., quoting Kermarec v. Compagnie Generale, 358 U.S. 625,630 (1959).

ts The circuit court supported its use of equitable principles by reliance upon the proposition that " [e]quity is no stranger in admiralty; admiralty courts are, indeed, authorized to grant equitable relief.'" $378 \mathrm{~F} .2 \mathrm{~d}$ at 582, quoting Vaughan v. Atkinson, 369 U.S. 527, 530 (1962). The application of equitable principles in admiralty courts has been given judicial recognition. See, e.g., United States v. Cornell S.S. Co., 202 U.S. 184, 194 (1906); Compania Anonima Venezolana De Navegacion v. A.J. Perez. Export Co., 303 F.2d 692, 699 (5th Cir.), cert. denied, 371 U.S. 942 (1962); United Transp. \& Lighterage Co. v. New York \& Baltimore Transp. Line, 180 F. 902, 905 (S.D.N.Y. 1910), aff'd, 185 F. 386 (2d Cir. 1911); Eagle, Star \& British Dominions v. Tadlock, 14 F. Supp. 933, 936 (S.D. Cal. 1936). For example, the physical hazards of a maritime venture give play to "equitable" principles, such as contribution on the general average, which are designed to afford protection for all interests subjected to these risks. See notes $41-43$ supra and accompanying text. Similarly, considerations of maritime hazard and "equity" led to the adoption of the moiety doctrine in collision cases. See note 46 supra. Moreover, in order to avoid common-law teclini. calities, equitable principles such as estoppel, laches, subrogation, and the rule per- 
bility must rest equally upon parties with coextensive maintenance and cure obligations in the absence of a violation of any duty to the seaman by either obligor..$^{50}$

Although admiralty courts are not generally empowered to grant affirmative equitable relief, ${ }^{60}$ they may incorporate appropriate equitable principles to resolve competing maritime policies. ${ }^{61}$ Moreover, reimbursement rights similar to those granted in Gooden are not unique in admiralty. ${ }^{62}$ Thus, the basic equitable rationale of the

mitting an agent to sue in his own name have become deeply rooted in the maritime law. See Flores v. The SS George Lykes, 181 F. Supp. 53 (D.P.R. 1960) (estoppel); New York Trap Rock Corp., 172 F. Supp. 638, 647 (S.D.N.Y. 1959) (subrogation); The Speybank, 28 F.2d 436, 437 (D. Md. 1928) (agent can sue in his own name); Comment, Admiralty: The Doctrine of Laches, 37 TuL. L. REv. 811 (1963).

On the other hand, admiralty will not grant equitable relief merely because the transaction in question is of a maritime nature. E.g., Swift \& Co. Packers v. Com. pania Del Caribe, 339 U.S. 684, 690 (1950). See generally 1 E. Benedict, The LAW of AMERICaN ADMIRALTY $\$ 71$ (6th ed. A. Knauth 1940, Supp. 1961) [hereinafter cited as BENEDICT]; 29 TEXAs L. REv. 244 (1950). For example, admiralty will not take jurisdiction of an action to set aside a sale of ships where the sale has been induced by fraudulent representations. E.g., The Captain Johnson, 64 F. Supp. 559 (D.N.J. 1946); The Managua, 42 F. Supp. 381 (S.D.N.Y. 1941). Neither will admiralty take jurisdiction to grant recovery of money paid because of false and fraudulent representations. Kaufman v. John Block \& Co., 60 F. Supp. 992 (S.D.N.Y. 1945). Equitable relief, however, has been granted where the equitable claim is presented defensively. See, e.g., Deitcher Bros. v. Skibs, 1942 A.M.C. 1466 (S.D.N.Y.). Moreover, equitable relief has been granted in an affirmative manner when subsidiary to, and necessary for, the effective preservation of a cause wholly maritime. For example, where a shipowner unjustifiably withholds maintenance and cure to the detriment of a seaman, the seaman is entitled to an equitable award of counsel fees to preserve the effectiveness of the maintenance and cure judgment, Vaughan v. Atkinson, supra, and where an admiralty court's power might be thwarted by a fraudulent transfer, a libel to set aside the transfer is within the purview of admiralty jurisdiction. Swift \&. Co. Packers v. Compania Colombiana Del Caribe, supra.

50 378 F.2d at 581 . The court stated that "[t]o the extent a shipowner proves that payments made in satisfaction of a maintenance and cure obligation have reduced or eliminated a concurrent claim which a seaman but for the prohibition against double recovery could assert against another party absent a release, the shipowner is entitled to reimbursement from the other party in such amount as will cause the ultimate liability to be placed: (I) by means of contribution, equally upon all shipowners with coextensive maintenance and cure obligations . . ." Id.

-o See generally 1 BENEDICT $\$ 71 ; 29$ TEXAs L. REv. 244 (1950). Affirmative equitable relief has been granted, however, for the preservation of an established maritime cause of action. See Vaughan v. Atkinson, 369 U.S. 527 (1962); Swift \& Co. Packers v. Compania Columbiana Del Caribe, 339 U.S. 684 (1950); note 58 supra.

${ }^{11}$ See note 58 supra. The equitable principle of contribution has traditionally been recognized in admiralty collision, see note 46 supra and accompanying text, and general average cases, see notes $4 I-43$ supra and accompanying text, as have equitable principles such as estoppel and laches, see Comment, Admiralty: The Doctrine of Laches, 37 TuL. L. REv. 811 (1963); 29 Texas L. REv. 244 (1950).

02 See notes $41-47$ \& 61 supra and accompanying text. Indemnity has previously been implied in favor of a shipowner who became liable solely because of the actions 
decision seems fundamentally consistent with admiralty principles. ${ }^{03}$ Nevertheless, the rules promulgated by the decision raise questions as to the mechanics of their application.

The immediate consequence of allowing contribution among coextensive maintenance and cure obligors is to avoid arbitrary imposition of ultimate liability, ${ }^{64}$ for a co-obligor is protected from having to absorb the full cost of maintenance and cure by virtue of his comparative availability to suit or the seaman's caprice or collusion with another interested party. ${ }^{65}$ But even the equal-division method of apportionment as selected in Gooden arguably fails as an optimum standard since it is unrelated to the fundamental nature of the maintence and cure obligation. The basic purpose of that obligation is to induce employment in the merchant marine by guaranteeing the seaman a certain degree of protection in return for services rendered.00 The onerous consequences resulting from the disregard of this prin-

of a third party. See, e.g., Crumady v. The Joachim Hendrik Fisser, 358 U.S. 423 (1959); Jones v. Waterman S.S. Co., 155 F.2d 992 (3d Cir. 1946).

${ }^{\circ}$ See 13 VILL. L. REv. 187, 188 (1967).

64 The court in Gooden emphasized that reimbursement rights remove from the hands of the original libellant the ability to control ultimate disposition of maintenance and cure responsibility among co-obligors. 378 F.2d at 580 .

es See also W. Prosser, Handbook of the LAw of Torts $\S 47$, at 275 (3d cd. 1964) [hereinafter cited as PROSSER]. It is arguable that contribution may impede loss distribution where one of the co-obligors is a poor "loss distributor"; i.e., a marginal operator whose elasticity of demand is greater than one, see D. WATSON, PRIce THEORY AND I'TS UsEs 30-31 (1963), and who is unable sufficiently to insure his shipping operation. Absent collusion or unavailability to suit, a scaman will most likely suc the more financially sound of two obligors. Cf. James, Contribution Among Joint Tortfeasors: A Pragmatic Criticism, 54 HARv. L. REv. 1156, 1162-63, 1167 (1941). Without contribution, liability would necessarily remain with the better loss distributor. On the other hand, the availability of contribution requires one-half of the expense to be borne by the poor loss distributor. The argument that a seaman would prefer to sue the less affluent shipowner to avoid a high-powered legal defense is not compelling since the liberal judicial protection of seamen leaves few issues of law open to legal scrutiny. Rather, re covery for maintenance and cure can be had upon the mere factual showing that the seaman's disability arose without wilful misbehavior on his part. See Norris, supra note 35 .

${ }^{66}$ The doctrine of maintenance and cure originated in the ancient codes which were enforced to achieve employee security and thereby encourage development of international trade by staffing and sustaining national merchant marines. See Levinson, Current Developments in the Field of Maintenance and Cure, 11 NACCA L.J. 140, 141 (1953); Comment, Admiralty Right to Maintenance and Cure, 38 ILL. L. REv. 193, 194 (1943). See also 1 NorRs $\$ \S 538$-39; note 16 supra. This motivation remains today with only slightly different emphasis: "If men are to go down to the sea in slips and face the perils of the occan, those who cmploy them must be solicitous of their welfare. Maintenance and cure is an inducement on the part of the masters and owners [to give seamen] ... a degree of security, though injury or sickness be in. curred." Farrell v. United States, 336 U.S. 511, 524 (1949) (Douglas, J., dissenting). 
ciple are illustrated by the situation in which the seaman is employed by one shipowner for several years before suffering a disability and, upon apparent recovery, is subsequently hired by a second shipowner in whose employ the disability soon recurs. ${ }^{67}$ Under Gooden, each shipowner would be required to contribute equally to expenses incurred after the seaman's employ with the second owner ${ }^{88}$ even though that employer profited far less from the seaman's services. ${ }^{60}$ Conversely, equal division will impose an even greater burden on the first shipowner when the second has had the benefit of the seaman's services for a relatively longer period since the first employer will more likely pay the greater proportionate part of the total maintenance and cure expense..$^{70}$ As between shipowners with coextensive duties, however, apportionment of liability according to services rendered would appear most consistent with the nature of the underlying maintenance and cure obligation. Moreover, services-rendered apportionment, a variation of the resolution previously employed successfully in calculating contribution in the general average, ${ }^{71}$ involves no operative difficulties. The determination of shares would most equitably be made upon the basis of the total medical and living expense rather than only upon that incurred subsequent to the second employ. ${ }^{22}$ Thus, the second shipowner would be liable for

07 The phrase "recurs" is used to denote the situation where an original injury elsewhere was the substantial factor in causing the subsequent disability, as happened in Gooden to create a coextensive maintenance and cure liability. See 378 F.2d at 580; note 3 supra.

${ }^{68} 378$ F.2d at 581 . See note 59 supra and accompanying text.

${ }^{\circ \theta}$ In Gooden the seaman was in Texaco's employ approximately sixty days, $255 \mathrm{~F}$. Supp. at 344, but in Sinclair's employ only ten, id. at 345 . Texaco, therefore, theoretically derived six times the benefit from Gooden's services realized by Sinclair.

${ }^{70}$ For example, assume the seaman was in the first shipowner's employ for just two days before the original injury occurred, and was disabled for two years. Prior to actual recovery, he might work two months for the second owner before his injury recurs. Subsequently, he is disabled another year until he achieves maximum medical recovery. Under Gooden the first vessel owner must pay $21 / 2$ years maintenance and cure expense while the second pays for only $1 / 2$ year.

${ }^{71}$ See notes $41-43$ supra and accompanying text.

73 The Gooden court considered solely the maintenance and cure expense incurred subsequent to recurrence of the disability since this was the only period of coextensive obligations. $378 \mathrm{~F} .2 \mathrm{~d}$ at 580 n.4. If apportionment is to be made according to relative benefit derived from the seaman's services, however, total maintenance and cure expense must be considered, since the first shipowner may pay a considerable portion of the expense before the obligation becomes coextensive. See note 70 supra and accompanying text. Note that because the second shipowner's obligation begins with recurrence of the injury, he can never be obligated for an amount in excess of the expense incurred after recurrence, 
the amount of total maintenance and cure costs equal to his fraction of the employment span over both employers, not to exceed the costs incurred subsequent to the attachment of his obligation. ${ }^{73}$ In this manner, each employer's cost would be directly related to the benefit received from the employment of the injured seaman. Appraised on the basis of ease of judicial administration, ${ }^{74}$ this system would delay computation of obligations little more than equal division since determination of length of service and recourse to a simple mathematical formula ${ }^{75}$ would provide the dollar amount of an award.

Regardless of the precise manner in which the maintenance and cure expense is allocated, the very fact of distribution may denote a gravitation from the Halcyon proscription of contribution among joint tortfeasors in non-collision cases. The Gooden emphasis upon equal distribution of a common burden ${ }^{76}$ and the necessity of pre-

${ }^{73}$ If Gooden were employed by Texaco for five weeks prior to his original injury, and by Sinclair for one week before recurrence of the injury, maintenance and cure expense would be apportioned in a ratio of five to one. Below is a simple math. ematical formula for determining apportionment:

$\mathrm{X}=$ period of seaman's employment with shiporner \#1

$Y=$ period of seaman's employment with shipowner \#2

$T=$ total amount of maintenance and cure expense to be apportioned

$\mathrm{S}=$ one share of this expense

Shipowner \#l's liability $=\mathrm{X} \cdot \mathrm{S}$

$$
\begin{aligned}
& \frac{1}{X+Y}=\frac{S}{T} \\
& S=\frac{T}{X+Y}
\end{aligned}
$$

Shipowner \#2's liability $=Y \cdot S$

Since the second shipowner could never be held liable for a seaman's maintenance and cure expense accumulated before the seaman's employment with him, see note 72 supra, one exception to the above general apportionment would have to be made. Assuming that $X$ and $Y$ are in a five to one ratio and the maintenance and cure expense totaled $\$ 11,000, \$ 10,000$ of which was accumulated after the seaman's employment with the first shipowner but before his employment with the second, the second shipowner would be liable for only $\$ 1000$. Admittedly, apportionment of expense in the case of this exception would not be strictly related to the period-of-employment basis, but the apportionment would still be closer to the relative benefits derived than apportionment under the Gooden rule. Under Gooden the respective obligation would be $\$ 10,500$ and $\$ 500$ instead of $\$ 10,000$ and $\$ 1000$.

${ }^{74}$ The promotion of unnecessarily complex litigation among shipowners which frustrates an indigent seaman's collection of maintenance and cure would in principle violate the traditional admiralty policy favoring the timely protection of seamen's rights. See generally Garrett v. Moore-McCormack Co., 317 U.S. 239, 246.48 (1942); Norris, supra note 35. But see Note, Wards of the Admiralty-An Anachronism?, 16 Geo. WASF. L. REv. 523 (1948).

${ }^{25}$ See note 73 supra.

${ }^{70} 378 \mathrm{~F} .2 \mathrm{~d}$ at 580 . See note 56 supra. 
cluding arbitrary imposition of liability ${ }^{77}$ may induce a future tempering of the Halcyon dictate. ${ }^{78}$ Although the precise holding of Halcyon is not traversed by Gooden, ${ }^{70}$ the latter is incompatible with the Supreme Court's rationale, for the new precedent makes no attempt to disparage the deference to legislative evaluation demanded by Halcyon. ${ }^{80}$ To the contrary, the implied dissatisfaction with congressional tolerance of archaic admirality traditions parallels the equitable tenor of criticisms which preceded the acceptance of contribution among joint tortfeasors at common law. ${ }^{81}$ Thus, if the Gooden court is representative of a broader based recognition of the need for more equitable liability distribution, the demise of other restrictive rules of contribution in admiralty may be forecasted.

Having determined that equity required joint satisfaction of the coextensive maintenance and cure obligation when neither party was at fault, the Gooden court further concluded upon the same basis that where one of the vessel owners had violated a duty owed the seaman, the entire expense should be borne by that employer. ${ }^{82}$ The circuit court emphasized that primary liability resides with the tortfeasor when his breach of duty is judicially determined concurrently with that of the maintenance and cure obligor. ${ }^{83}$ Reasoning that primary liability should not vary merely because the seaman has proceeded initially upon his non-tort claim, the court deduced that

77 See 378 F.2d at 580; note 64 supra.

${ }^{78}$ Since Halcyon is distinguishable on its facts from previous cases allowing indemnity among joint tortfeasors in non-collision cases, see note 52 supra and accompanying text, a court might consider the broad no-contribution dictate as mere dictum, limit the case to its facts, and allow contribution. See Staring, supra note 44 , at $305 \mathrm{n} .9,345$.

${ }^{70} \mathrm{In}$ its promulgation of the no-contribution principle, the Halcyon Court was concerned exclusively with the reimbursement right of parties whose duty to pay arose upon their negligent act. See Halcyon Lines v. Haenn Ship Ceiling \& Refitting Corp., 342 U.S. 282, 284-85 (1952); notes 48-53 supra and accompanying text.

${ }^{80}$ See notes $54-55$ supra and accompanying text.

${ }^{81}$ According to one authority, "half a century of vigorous attack upon the original rule [denying contribution] has had its effect in the passage of statutes in some twenty-three states, which to a greater or less extent permit contribution among tortfeasors." Prosser $\$ 47$, at 275. See generally Gregory, Contribution Among Tortfeasors: A Uniform Practice, 1938 WIs. L. Rev. 365; 32 Colum. L. REv. 94 (1932); 45 HARV. L. Rev. 349 (1931).

ss 378 F.2d at 581: "[U]ltimate liability [will] be placed . . . by means of exoneration, fully upon the party with a primary obligation in damages arising out of negligence, unseaworthiness, or other violation of duty."

${ }^{88} \mathrm{Id}$. See note 27 supra and accompanying text. 
the shipowner required to satisfy such a claim was entitled to exoneration from the tortfeasor. ${ }^{84}$

The concept of exoneration promulgated in Gooden differs substantially from previously utilized indemnity principles. Though indemnity generally has arisen in favor of a maintenance and cure payor only if there is a contract between the tortfeasor and the payor from which a duty of due care can be implied, ${ }^{85}$ reimbursement under the Jones rationale is based upon the tortfeasor's duty to reimburse the employer for services of an employee lost by virtue of the tort. ${ }^{86}$ Neither of these principles were applicable in Gooden since at the time of the original injury no relationship existed between the second owner and either the seaman or the alleged tortfeasor. ${ }^{87}$ The concept of exoneration utilized by the circuit court must not, therefore, arise from a duty of due care toward the indemnitee. Rather, the rationale appears to be founded exclusively on the equitable principle that primary liability for maintenance and cure expense should reside with the wrongdoer since he will pay only that which could be recovered from him by the seaman in an action for compensatory damages. ${ }^{88}$

Although Gooden was concerned solely with reimbursement

8* See note 82 supra.

${ }^{86}$ See Weyerhaeuser S.S. Co. v. Macirema Operating Co., 355 U.S. 563 (1958); H-10 Water Taxi Co. v. United States, 252 F. Supp. 592 (S.D. Cal. 1966). But see Crumady v. The Joachim Hendrik Fisser, 358 U.S. 423 (1959) (implied indemnity available where there is no actual contract). In Crumady, however, the indemnitor was performing services aboard the indemnitee's vessel, thus perhaps giving rise to the requisite relationship.

${ }^{86}$ Jones v. Waterman S.S. Corp., 155 F.2d 992, 998 (3d Cir. 1946). Sce note 34 supra and accompanying text.

${ }^{87}$ See 378 F.2d at 578. At the time of the original injury, the scaman was neither in the second shipowner's employ nor was there a contractual or service relationship of any kind between the two owners on which a duty of due care as to the health of the seaman could be predicated. Id.

88 There is a significant body of authority in admiralty and related arcas granting non-contractual indemnity on the basis of unjust enrichment. See, e.g., Simpson Timber Co. v. Parks, 1966 A.M.C. 1081 (9th Cir. 1965), rev'd upon rehearing on other grounds, 369 F.2d 324 (9th Cir. 1966), rev'd per curiam, 388 U.S. 459 (1967). See generally Note, Shipowner's Indemnity: Non-Contractual Recovery of Maintenance and Cure Expenses From Third Party Tort-Feasor, 18 Hastincs L.J. 1008 (1967). Nevertheless, prior to Gooden no court had allowed recovery to an indemnitee who was commercially unrelated to the indemnitor or the original libellant at the time of the tortious act. Nonetheless, the Gooden view of exoneration can be justified on the traditional theory that the wrongdocr would be unjustly enriched if the faultiess payor were made to compensate for any portion of a loss caused by the former. Cf., e.g., Crumady v. The Joachim Hendrik Fisser, 358 U.S. 423 (1959); Simpson Timber Co. v. Parks, supra. 
rights among shipowners, the theory of exoneration may have a broader application. In particular, the court spoke in general terms of a shipowner's right to exoneration from "another party"89 rather than merely from "another vessel owner." Moreover, the policy of uniform ultimate liability emphasized in Gooden ${ }^{90}$ is apparently relevant irrespective of the commercial status of the party liable in damages. Therefore, a non-negligent payor's right to reimbursement may comprehend the situation where the seaman's injury, stemming originally from the tortious act of one other than a vessel owner, was "heightened" 91 in the payor's service. Allowing a payor this recovery may be justified since the ultimate obligor is paying no more than that which could arguably have been recovered from him. ${ }^{92}$ Yet, where the non-shipowning tortfeasor is a natural individual, his opportunities to distribute loss may be significantly less than those of a shipowner. Thus, loss distribution analysis may suggest that exoneration should be restricted solely to actions among shipowners. ${ }^{93}$ No language in the Gooden opinion, however, necessitates limitations on the applicability of the reimbursement rule.

Although the Gooden court articulated procedural rules to meet the objection that its opinion would result in an increase in litigation which might delay a seaman's recovery, ${ }^{94}$ potential detriment of this sort could be attenuated by encouraging extra-judicial settlement. While a potentially liable party would normally have little reason to seek a release when the extent of his obligation might be expanded by a subsequent reimbursement award to a co-obligor, settlement might be promoted if a release secured therefrom were

${ }^{80} 378$ F.2d at 581. "To the extent a shipowner proves that payments made in satisfaction of a maintenance and cure obligation have reduced or eliminated a concurrent claim which a seaman but for the prohibition against double recovery could assert against another party absent a release, the shipowner is entitled to reimbursement ... by means of exoneration ...." Id. (emphasis added).

${ }^{\circ}$ Id.: "Given this fact that a seaman who joins two defendants in one suit is required to execute primarily on his damages judgment and only secondarily on his maintenance and cure judgment, the ultimate result should not be different here because the seaman has proceeded first upon his maintenance and cure claim."

o1 See note 3 supra.

${ }^{23}$ See GILMORE \& BLACK $\$ 6-18$, at 276.

${ }^{03}$ See note 65 supra, suggesting that loss distribution problems will arise even where the maintenance and cure obligation is apportioned among shipowners.

ot The circuit court stressed that the seaman's recovery was not to be restricted to the party ultimately liable, $378 \mathrm{~F} .2 \mathrm{~d}$ at $579 \mathrm{n.3}$, and instructed a trial court which had all parties before it to determine the seaman's rights before proceeding to issues of reimbursement, id. at 582 n.5. 
given the effect of relieving the settling obligor's reimbursement duty. Whether a release was envisoned by the Gooden court as having that effect is unclear, ${ }^{95}$ although the opinion does indicate that a release of one co-obligor would not exonerate all.ov Even absent a definitive specification, placing the power to limit a party's obligation in the hands of the libellant is inconsistent with Gooden's primary objective of precluding arbitrary imposition of liability, ${ }^{07}$ since opportunities for collusion and discrimination remain.

In disregarding superfluous technicalities, Gooden convincingly alters and expands reimbursement rights among simultaneous maintenance and cure obligors. Perhaps more importantly, the emphasis placed by the court upon achieving an equitable imposition of ultimate responsibility between parties possessing joint liabilities may presage a trend away from the impediments to contribution in analogous areas of maritime law. While future precedents can reevaluate the potential inequities of the equal-division method of contribution, attempts should be undertaken to preserve the divergence made by Gooden from outdated admiralty procedures.

\footnotetext{
${ }^{95}$ The relevant portion of the Gooden rule concerning releases is as follows: "To the extent a shipowner proves that payments made in satisfaction of a maintenance and cure obligation have reduced or eliminated a concurrent claim which a seaman ... could assert ... absent a release, the shipowner is entitled to reimbursement . ..." 378 F.2d at 581 (emphasis added). This language may be given contrasting interpretations as to the effect of a release on reimbursement rights: (1) the broad interpretation would give the shipowner a reimbursement right unless a release of the prior obligor occurred before the second shipowner's liability arose and thus before there were concurrent claims, see 13 VirL. L. REv. 187 (1967); (2) the limited interpretation would give the shipowner no reimbursement right if there were a relcasc of the concurrent claim at any time before the seaman asserted his claim against the shipowner.

${ }^{80} 378$ F.2d at 580 n.4. If the seaman releases the first co-obligor for a small consideration, the second remains liable for the balance of the maintenance and curc expense.

${ }^{\circ 7}$ See id. at 580-81; note 63 supra and accompanying text. But see 13 VILL. L. REV. 187, 192 (1967).
} 